\title{
Back to basics: Behavioral theory and internationalization
}

\author{
Irina Surdu ${ }^{1}$, \\ Henrich R. Greve ${ }^{2}$ and \\ Gabriel R. G. Benito ${ }^{3}$ \\ ${ }^{1}$ Warwick Business School, The University of \\ Warwick, Coventry CV4 7AL, UK; ${ }^{2}$ INSEAD, 1 Ayer \\ Rajah Avenue, Singapore 138676, Singapore; ${ }^{3} \mathrm{BI}$ \\ Norwegian Business School, Nydalsveien 37, \\ 0484 Oslo, Norway
}

Correspondence:

GRG Benito, BI Norwegian Business School, Nydalsveien 37, 0484 Oslo, Norway

e-mail: gabriel.r.g.benito@bi.no

\begin{abstract}
International business (IB) scholars' over-reliance on a select few theories leaves our understanding of firm internationalization incomplete. The behavioral theory of the firm (BTF) can offer new insights and can be used to model a broad range of firm actions. We focus on the three basic BTF components: problemistic search, learning by doing, and vicarious learning. These components help us understand why firm behaviors are more dynamic and heterogeneous than other theories allow. BTF, with its emphasis on how firms assess performance according to aspiration levels, selectively learn and update routines, and selectively incorporate the learning of others, is better suited to examine the diversity and change increasingly observed in internationalization decisions. We explain why scholars should move beyond "dynamizing" static theories and show BTF's applicability to behaviors involving change such as multi-mode market entries and market re-entries. BTF also helps examine the decision to internationalize in the first place, nascent firm internationalization, location choices, international market adaptation, and headquarter-subsidiary relationships. We encourage IB scholars to use theories that can handle the complexity increasingly associated with modern firm growth, and propose BTF as a promising starting point.
\end{abstract}

Journal of International Business Studies (2021) 52, 1047-1068. https://doi.org/ | 0. I057/s4 I 267-020-00388-w

Keywords: behavioral theory; dynamic MNE behavior; problemistic search; learning by doing; vicarious learning; internationalization theory

The online version of this article is available Open Access

\section{INTRODUCTION}

For the past five decades, the scholarly focus in the field of international business has been on how multinational enterprises (MNE) generate rent by effectively utilizing their resources and capabilities in attractive international markets. Recent comprehensive reviews and commentaries point out the progress made in IB research, but also claim that there are limitations against continuing this progress (Buckley, Doh, \& Benischke, 2017; Delios, 2017; Rugman, Verbeke, \& Nguyen, 2011). First, because international business is always changing, IB theories should put dynamics centrally in their epistemology. This requires going beyond "dynamizing" essentially static theories to focus more on how
Received: 22 May 2020

Revised: 2 October 2020

Accepted: 22 October 2020

Online publication date: 3 December 2020 
specifically firm behaviors change over time. Second, because it involves different contexts and firms, international business is also heterogeneous, which calls for theorizing that is both suitably general and sufficiently flexible to accommodate diversity in firm decision-making. The dynamism and diversity observed in firm behavior (Puig, Madhok, \& Shen, 2020; Santangelo \& Meyer, 2017) suggests that internationalization decisions are more complex than current models would predict, partly reflecting different decision-maker experiences, goals and expectations. Also, decisions made in an international context require some level of flexibility as firms inevitably face varying levels of uncertainty and may regularly need to adjust their behavior in different markets (Aharoni, Tihanyi, \& Connelly, 2011). A narrow and static view of internationalization is, thus, inappropriate.

There are two dominant theoretical perspectives used in IB to study internationalization: the Uppsala model (Johanson \& Vahlne, 1977, 2009) and internalization theory in its various iterations (Narula, Asmussen, Chi, \& Kundu, 2019); see Buckley and Casson (1976), Hennart (1982), Rugman (1980), and Teece (1986). In their original form, both the Uppsala model and internalization theory incorporated behavioral assumptions, which have, over time, faded from scholarly focus, making room for more simplistic explanations concerning firm behavior. In the original Uppsala model, the emphasis on uncertainty avoidance and learning by doing follows behavioral principles, but the subsequent applications of the model assumed that a firm's environment remains stable over time; implicit in this assumption is that, following a long period of learning-by-doing, firms will acquire a sufficient amount of market knowledge in order to reduce uncertainty and make more informed, almost rational-like decisions (Foss \& Weber, 2016). The model makes a reference to dynamism (see Johanson \& Vahlne, 1977, p. 30), but mostly disregards the changing and varying nature of management incentives and expectations to move past the initial export step, and their effect on the decision-making process. The international investment decision is rarely the result of progressive reasoning (Aharoni, 1966) with factors in the internal and external environment of the firm eventually influencing investment choices. Because the Uppsala model has not provided sufficient emphasis and insight into aspects such as opportunity identification and development (Petersen, Pedersen, \& Sharma, 2003), its empirical applications have become highly deterministic over time, limiting its predictive value. Added assumptions of cumulative learning and environmental stability have narrowed the scope of the model to contexts and firms that fit such assumptions - the behavioral theory of the firm is more basic, and hence more flexible.

Internalization theory also mentions bounded rationality, again following behavioral theory assumptions that there are natural limits to processing information and making strategic decisions. Internalization theory proponents, however, address the problem of bounded rationality mainly through the "cost of information" logic (see Casson, 1999, 2000). This reasoning relies on an assumption of near-optimal reactions to missing information or limited information processing capabilities, which narrows the scope of the theory to contexts and firms with sufficient knowledge to meet the assumption. Again, the behavioral theory of the firm is more basic, and hence more flexible. This paper discusses how and why the behavioral theory of the firm offers important insights into understanding modern MNE behaviors, which traditional IB theories have only distantly drawn upon so far.

Our discussion is not intended as a critique of traditional IB theories. Instead, we propose that the behavioral theory of the firm (Cyert \& March, 1963), as discussed here, is a complementary perspective for analyzing firm behaviors that are often overlooked, or narrowly explained, using extant theory. We start by explaining how the behavioral theory of the firm can provide new insights in the field of IB and help exploration of increasingly common, but neglected internationalization behaviors. As such, we focus our discussion on two main questions: How does behavioral theory fit with what we already know about internationalization decisions? How can behavioral theory answer questions about firm internationalization that have not been answered effectively using extant theory?

To illustrate the utility of the behavioral theory of the firm, consider the key decision of entering a foreign market. Entry mode research has focused on the discrete choices that firms make on market entry, and adequately explains, for example, entry through exporting, which is a common entry mode, or whether a firm chooses instead to establish a foreign subsidiary in the country, thereby entering through an ownership-based mode (Anderson \& Gatignon, 1986; Brouthers \& Hennart, 2007). Firms that practice multi-mode entry 
strategies, however, remain a puzzle for extant theories. Such strategies involve the simultaneous use of more than one operation mode - i.e., the concurrent use of market-based, cooperation-based, and/or ownership-based organization modes - in conducting a given activity in various locations (countries) or conducting several activities in one or more locations (countries). Evidence suggests that the use of multiple, rather than distinct singular modes, is, in fact, increasingly widespread (Benito, Petersen, \& Welch, 2009, 2011; Clark, Pugh, \& Mallory, 1997; Putzhammer, Fainshmidt, Puck, \& Slangen, 2018).

The evidence concerning the use of multiple modes, however, fits extant theory poorly. For instance, the Uppsala model is primarily used to predict a progression in modes given adequate learning, evolving business relationships, and positive performance. It predicts a transition from simple and modest modes (such as market transactions), to more demanding ones in terms of commitment and risk, until the firm has the resources and capabilities needed to reduce host market uncertainty and set up a wholly owned subsidiary. The firm evolves from one step to another, shedding simpler ways of organizing and adopting more demanding ones as it moves forward along in its internationalization path. As such, the idea of multiple modes goes against the Uppsala model logic, inasmuch as using multiple modes is contrary to the prediction of a steady transition. Similarly, research based on internalization theory has typically focused on singular mode choices - presumably what has been regarded as the main mode but does not predict singular mode choices. It does not predict multiple mode choices either, due to its focus on the costs of performing value activities, which may vary across contexts, requiring different ways of organizing them efficiently (Benito, Petersen, \& Welch, 2021). Although firms that conduct several value activities, in one or several locations, may rationally employ multiple modes, the observability of these costs is sufficiently poor that traditional IB theories do not make easily testable predictions.

Next, consider the post-internationalization firm behavior as another example. Foreign market reentry occurs when a firm returns to an international market it has previously exited, either as a partial exit such as a significant decrease in export intensity, or total exit such as when the firm no longer sells its products or services in the market (Benito \& Welch, 1997; Welch \& Welch, 2009).
Research on re-entry finds that it is a frequent occurrence (see Aguzzoli, Lengler, Sousa, \& Benito, 2020; Surdu, Mellahi, \& Glaister, 2019; Surdu, Mellahi, Glaister, \& Nardella, 2018; Surdu \& Narula, 2020). Again, evidence concerning exit and re-entry behaviors fits extant theory poorly. The Uppsala model of internationalization assumes that firms learn by acquiring experience in a market, which, over time, becomes a source of increased confidence and increased market commitment. It is a model of increasing commitment except when failure to perform in that market indicates a need to retreat. Re-entrants follow a non-monotonic growth model, whereby they enter a market, exit, and may or may not increase commitment upon re-entry. For re-entrants, the experience accumulated in the market during the initial entry may be difficult to interpret or not be perceived as relevant, particularly after a period of time-out which may have led to organizational forgetfulness as well as alterations in the external environment of the firm. Overreliance on utilizing internal capabilities such as past experience, may lead firms to employ the same strategies that have been unsuccessful in the market, upon re-entry (Surdu et al., 2019). Furthermore, post-internationalization decisions such as exit and re-entry are also a poor fit to internalization theories. The high transaction costs associated with returning to a previously failed market, where the firm clearly does not have superior firm-specific resources to successfully leverage for competitive advantage, makes re-entry improbable. Were the MNE to reenter, it would not be expected to commit significant resources to the previously exited market.

Multi-mode strategies and foreign market reentry post exit are examples of commonplace internationalization behaviors that remain understudied in part - we argue - because they demonstrate dynamic and complex firm internationalization behaviors that are a poor fit with the commonly used IB theories. Theories that predict static regularity will be drawn to static and regular behaviors. However, dynamic behaviors are not anomalies, nor can they be classed as outliers. Rather, they exemplify lacunae that call for thoughtful scholarly engagement. For ambitious IB scholars, they are opportunities to explore theories that can enrich our understanding of internationalization and improve our claim to managerial relevance. We propose the behavioral theory of the firm as a theory that offers suitable explanations for dynamic firm behaviors such as 
multi-mode and re-entry strategies, and also for several other internationalization-related decisions, as we will demonstrate later in this paper. We also highlight that existing IB theories which draw on behavioral theory foundations, can be strengthened and deepened if the behavioral theory of the firm was to be applied more rigorously.

In the remainder of this paper, we present key elements of behavioral theory and propose applications to various internationalization behaviors. We start with a discussion of the theory and its elements of problemistic search, learning by doing, and vicarious learning. Then, we consider how the behavioral theory of the firm (as we propose it) may be used to study selected internationalization decisions such as examining internationalization motivations, nascent multinationals, international location choices, international market adaptation, and the headquarter-subsidiary relationship. We end with a broader discussion of how behavioral theory can, in our view, inspire IB research.

\section{THE BEHAVIORAL THEORY OF THE FIRM}

How does the behavioral theory of the firm fit with what we already know about internationalization decisions? The behavioral theory of the firm views the firm as a coalition of key stakeholders such as managers, shareholders, employees and customers, amongst others, each with their own goals and expectations; importantly, these goals and expectations become adjusted over time in response to relevant changes in the firm's environment (Cyert and March, 1963). ${ }^{1}$ Since firms have to consider many different goals, at different points in time, there is not a simple relationship between these goals and the subsequent decision-making processes designed to achieve those goals. Organizations themselves vary based on the amount of importance (and thus, resources) allocated to specific goals at a given point in time. The essential pieces of the behavioral theory of the firm are condensed into the famous Chapter 6 (in the first edition) of Cyert and March (1963: 114-127).

Specifically, firms do not optimize, they satisfice, which means that on each performance goal, performance above the aspiration level is sufficient, but performance below the aspiration level initiates problemistic search. Problemistic search, in turn, is myopic through its focus on the source of the problem and the current activities of the firm, and it is persistent until performance is brought above the aspiration level or the aspiration level is lowered. Because there are multiple goals and coalitions monitoring each goal, the firm is in a state of quasi-resolution of conflict. It is also made more rigid through uncertainty avoidance, through emphasizing near-term goals and through seeking to negotiate a predictable environment. Finally, organizations and their participants learn. Organizations may repeat actions that have had prior success, while participants may show a bias in favor of solutions that they are familiar with through training, experience or observation.

Although these are currently the most important elements of the behavioral theory of the firm, they are far from the only with potential use. The theory had extensive coverage of standard operating procedures, which has become a research stream on organizational routines and their effects on firms (Becker, 2008). It covered organizational politics and the rise of dominant coalitions in management, which has a modern equivalent in research on top-management team composition (Hambrick, Cho, \& Chen, 1996; Hambrick \& Mason, 1984). Finally, there is a rich research stream on how organizations search for either proximate solutions (exploitation) or distant opportunities (exploration) (Lavie, Stettner, \& Tushman, 2010), inspired by a later seminal organizational learning paper (March, 1991). This theory has been followed by, and is consistent with, much later theory and evidence on how different forms of experience and subsequent learning help firms build routines and change their strategic behaviors (e.g., Kogut \& Zander, 1992; Nelson \& Winter, 1982).

Figure 1 provides a behavioral model linking the individual and organizational characteristics associated with MNE decisions to three inter-related theoretical mechanisms: problemistic search, learning by doing and vicarious learning. We explore these theoretical mechanisms in detail below.

\section{Problemistic Search}

The theory of problemistic search has developed into a major research stream on the effects of performance feedback, started by papers showing that performance relative to aspiration levels, in fact, led to market entry and exit (Greve, 1998) as well as other strategic decisions such as $R \& D$ and innovation launches (Greve, 2003). This work exceeds 100 empirical papers and has been reviewed multiple times (Gavetti, Greve, Levinthal, \& Ocasio, 2012; Kotiloglu, Chen, \& Lechler, 2019; Posen, Keil, Kim, \& Meissner, 2018; Shinkle, 2012), with scholars in agreement about its potential and 


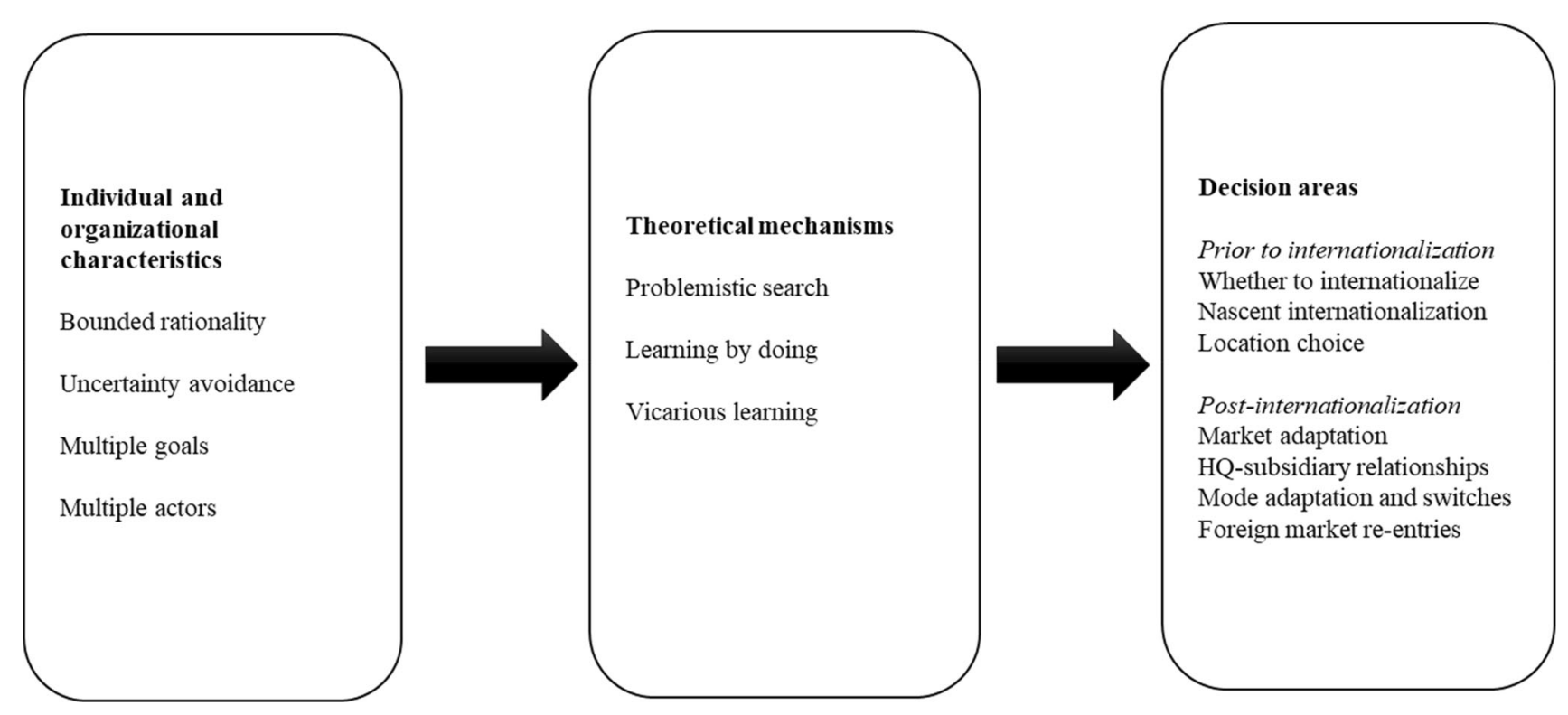

Figure 1 Behavioral model of the characteristics, mechanisms and outcomes of MNE strategic decisions.

usefulness to examining strategic decisions, including IB decisions such as corporate internationalization (Jung \& Bansal, 2009) and international market development (Su \& Si, 2015).

The theory and empirical conclusions on problemistic search are clear. First, as theorized by Cyert and March (1963), organizations compare their performance on each goal with aspiration levels, which, in turn, are determined through comparisons with peers and with past performance. This means that the performance level that is categorized as a failure, and hence triggers search, differs from firm to firm but is predictable from its past performance and the performance of similar firms (Bromiley \& Harris, 2014; Greve, 1998). Second, organizations have multiple goals. The goals that tend to trigger the most diverse forms of search, and the strongest responses, are profitability and closely related goals such as market share (Greve, 2008; Shinkle, 2012). Third, problemistic search usually uncovers modifications of current activities as solutions, and these modifications are guided by the specific goal shortfalls (Baum \& Dahlin, 2007; Gaba \& Greve, 2019; Kuusela, Keil, \& Maula, 2017). This research has moved into examining the goal conflicts in multi-unit organizations typical for MNEs (Gaba \& Joseph, 2013).

The theory of problemistic search is a different lens on behaviors related to internationalization, and immediately suggests propositions related to our initial examples around multi-mode and reentry behavior. Multi-mode entry strategies are consistent with the behavioral theory of the firm because it does not rank entry modes by level of complexity or commitment. Central statements in the theory are that organizations learn from their experience and develop routines, which implies that firms will differ in their degree of multi-mode entry as a predictable result of their experience. A firm that has used multiple modes of entry before, either in different locations or through evolution as specified in the Uppsala model, will have routines in place for each mode. If these past uses are perceived as successful, the MNE will draw freely from them when entering a new market depending on contextual differences such as availability of resources or estimates of the best-fit entry mode. Indeed, the specific choice may be predictable if taking into account that the learning from experience also involves matching of current decisions to past decisions and outcomes (Cyert \& March, 1963: 125-127). Yet, the outputs of one decision made are not necessarily the inputs of another. Decision makers are likely to compare market characteristics and choose the mode used in the most similar past entries, unless they were unsuccessful, in which case, one mode associated with multiple unsuccessful entries is less likely to be used. Given the premise that search is problem-oriented, we also consider that the rules of the search may be altered over time. Hence, from a problemistic search lens, mode choices are not so easily predictable, as firms dynamically adjust when they encounter problems by, in this example, adding new inputs (knowledge, 
information) into the subsequent mode choice, whilst old inputs are, in part, disregarded. The focus is oriented towards matching strategies to firm contexts rather than calculating options or consequences.

Similarly, when MNEs search for solutions to a problem of low performance in a host market, one form of myopic search is to adjust their international presence, in the form of retreats or further investments. Indeed, it has been shown that the manner in which low profitability combines with overall resources predicts investment expansion versus investment reduction as a response (Kuusela et al., 2017). Firms also learn from their experience, so a retreat from one market would normally result in learning that the market is difficult, or that the MNE lacks the necessary resources and capabilities to succeed, and hence should not re-enter that market. Importantly, the lessons drawn from singular events such as a market retreat are unpredictable (March, Sproull, \& Tamuz, 1991), and are dependent on how the MNE frames the causes associated with underperformance and thus, the retreat. The top management team may frame the underperformance as one caused by an incompetent country manager or attribute it to bad timing such as a slump in demand, so at a time in which expansion is seen as the correct solution, a re-entry may appear to be a better choice than entering a new market. Indeed, a later search for a solution to low corporate performance may suggest re-entry into a familiar market as a myopic solution. This is likely considering the effect of dominant coalitions on decision-making, as a setback in one market weakens a dominant coalition favoring internationalization. The dominant coalition will still favor internationalization and may re-enter the market after identification of a suitable scapegoat. Importantly, myopic search driven by MNE goals can lead to strategic solutions being categorized differently, so instead of deciding what do to with a host market, the firm's executives end up deciding where to expand. Insights from problemistic search and dominant coalition theory would show that reevaluations of search rules and different problem framing can produce distinctive strategic decisions. Further, there are difficulties in placing boundaries around organizational coalitions - at different points in time, different coalitions may be specified. In contrast with past theorizing, we discuss decision alternatives in response to strategic problems not necessarily strategic opportunities.

\section{Learning by Doing}

Organizations learn from their own experience through direct learning by doing, interpretation of the organizational history, and selective recording and retrieval of experiences (Levitt \& March, 1988). This gives organizations stable sets of routines both of the kind that are executed repeatedly and of the kind that are executed in response to specific situations (Feldman, 2000; Feldman \& Pentland, 2003). There are multiple research streams documenting how such learning produces behavioral patterns in organizations that can be predicted and understood from their experiences. For instance, research on acquisitions has found that rate of acquisition, selection of acquisition target, and integration of target are all subject to learning from experience (Barkema \& Schijven, 2008; Haleblian, Kim, \& Rajagopalan, 2006; Trichterborn, Zu Knyphausen-Aufseß, \& Schweizer, 2016). Research on alliance formation and performance has generated similar findings (Anand \& Khanna, 2000; Barkema, Shenkar, Vermeulen, \& Bell, 1997; Gulati, Lavie, \& Singh, 2009), with scholars explaining that firms would benefit from acquiring market and institutional knowledge in order to enhance their firm-specific advantages and effectively engage in international partnerships (Collinson \& Narula, 2014; Narula, 2012, 2014). Research on the internationalization decision itself relies significantly on experience accumulated over time as a source of learning (Casillas, Barbero, \& Sapienza, 2015; Sapienza, Autio, George, \& Zahra, 2006), with fewer studies starting to recognize that firms learn from different types of experiences (Gong, Zhang, \& Xia, 2019; Zeng, Shenkar, Lee, \& Song, 2013). Studies focusing on experiences that produce learning and routines which are executed in response to specific situational characteristics, tend to be even more scarce (but see Arikan \& Shenkar, 2013; Chang \& Rosenzweig, 2001; Perkins, 2014).

Research on learning by doing has become prominent, and repetition of strategic actions is so common that analysts control for it when examining different learning processes. For instance, research on the diffusion of new technologies and strategic actions among firms routinely controls for such repetition in firm strategies (Compagni, Mele, \& Ravasi, 2015; Greve, 2009; Miller \& Chen, 1994). Importantly, however, findings suggest that firm behavior goes beyond repetition, as there is clear evidence that repeated 
strategic actions are done with greater sophistication as a result of the learning they enable (Dekker \& van den Abbeele, 2010; Lavie, Kang, \& Rosenkopf, 2011; Zollo \& Reuer, 2010).

The findings on the effects of learning from experience are closely related to a large research stream on how organizations build up and exploit sets of routines either for continuous use or for use contingent on specific events (Becker, 2008). A key issue for understanding this literature is that learning by doing, or learning from own experience, is no longer restricted to the conception of routines as actions that are repeatedly done by small groups of people as part of the regular production (Nelson \& Winter, 1982). Instead, routines can be seen as recipes that are used flexibly to produce specific outcomes, or more generally, as grammars of actions that start with specific experience and can be varied to take into account environmental demands and changes (Pentland \& Rueter, 1994). This view of routines is more flexible than the traditional one, but it still implies that organizations vary in their ability to adapt depending on how broad their experience is, and how well it has been recorded into organizational memory (Feldman \& Pentland, 2003).

To the extent firms use multiple modes, they are more likely to choose modes that are relatively similar to each other, as a way to utilize the knowledge and routines they already have and reduce the need for additional learning. For example, market-based operations and contractual operations share the key characteristic of involving separate firms doing business with each other. While the regularity and time horizon typically differ between the two modes of operation markets transactions may be serendipitous, transient, and flexible, whereas the nature of contracts is to establish and structure a lasting bond within specifically agreed parameters - both operation modes entail keeping a clear interface between actors. Thus, operating both modes concurrently imposes few additional organizational strains on the firm. Similarly, both a joint venture and a wholly owned subsidiary imply setting up entities that are integrated with the rest of the organization. Both modes require largely the same organizational routines to run effectively, so operating them alongside each other does not typically require significant adjustments, although managing a joint venture may entail additional challenges due to its shared ownership. These conjectures are already consistent with work on how firms convert learning from one type of experience into better performance on closely related forms of experience (Zollo \& Reuer, 2010). Conversely, operating multiple modes that share few characteristics represents hurdles that make their simultaneous use less likely. These predictions follow readily from a view of learning new routines from own experience, and they are easily testable. Clearly, firms using multiple modes can be explained by this mechanism, and the theory predicts that the likelihood of doing so (and the resulting performance) is a function of experience associated with each mode.

\section{Vicarious Learning}

Organizations can also learn by observing the actions of other firms and noting the outcomes of those actions. Vicarious learning (Duysters, Lavie, Sabidussi, \& Stettner, 2019; Ingram \& Baum, 1997; Kim \& Miner, 2007; Myers, 2018) involves making meaning of, and imitating (most likely with some adaptations), the actions or characteristics of other organizations, in the belief that emulating them is associated with a higher likelihood of achieving a better result than if the focal firm would make its decisions in isolation, perhaps through a lengthy and risky process of trial-and-error (Duysters et al., 2019; Haunschild \& Miner, 1997). As a shortcut to learning, identifying positive outcomes (with some regularity) reinforce beliefs about the appropriateness of those actions, whereas spotting negative outcomes may lead to avoiding the actions perceived to have caused them. This type of learning is particularly important for the modern MNE, perhaps more so than knowledge acquired mainly through experience of operating abroad. Advancements in IB have recognized the importance of learning from others (Johanson \& Vahlne, 2009) but still focus on learning as a replication of positive behavior.

Of course, the conjunction of actions and outcomes is, at times, an uneasy one. Sometimes actions can be observed, but not outcomes, perhaps because the process of producing an outcome is lengthy (Kim \& Miner, 2007). Sometimes, outcomes can be observed, but it is hard to link them to a specific action because the cause-effect relation is ambiguous, or because the outcome is due to a combination of several actions (Myers, 2018). Either way, the focus on positive replications of routines and strategies is problematic. The organizations and strategies that are often observed, are those which have survived the selection process and achieved success (Denrell, 2003). Focusing on 
the behavior of successful firms may bias the observations of managers, and thus the lessons learned through vicarious learning.

The earlier findings concerning the effects of vicarious learning, suggest that firms most effectively learn from the failures or near failures of other firms (Ingram \& Baum, 1997; see also Kim \& Miner, 2007). In practice, the management of MNE activities is more dynamic and involves a regular reevaluation of investments in international markets by, for instance, partial divesting from markets where the MNE is under-performing (which can involve a switch from a full ownership mode to a market-based mode) and increasing investment in markets where the MNE is more likely to achieve a dominant position (therefore switching to higher commitment, ownership-based modes of operation). In more extreme cases, firms are forced to completely divest their market operations, in which case, they formulate new international strategies to reallocate resources or seek for ways in which to re-enter.

The mechanism of vicarious learning, we propose, is a likely candidate to understand the manner in which MNEs dynamically alter their strategic behavior in international markets. For instance, in the case of exit and re-entry, vicarious learning would involve multiple processes: industry-level under-performance can mean near-failure for firms and trigger them to search for new strategies or new markets; provide an example of what activities to undergo and avoid; provide an example of how to manage local competitors and institutional actors or how to negotiate with old or new partners; provide an opportunity to look for new markets to enter and sustain growth goals. Own experience often presents only part of this information at a given point in time. Firms may not learn from their own failures in a timely manner (Kim \& Miner, 2007) either because the failure is too traumatic in the short term or because relevant decision makers may have left the company. Learning from others' failure may incentivize firms to engage in search activities, as they are still able to avoid their own underperformance. Importantly, MNEs which have experienced a near failure but have strategically recovered (e.g., firms which only partially exited, or which re-entered) provide other firms with the conditions that can threaten their own survival but also with the strategic options to recover from failure. Learning from firms which have both failed and have managed to recover (e.g., re-entrants) provides a good indication of the symptoms of a problem (what happened and why) but most importantly, its cure (a proven solution).

At the same time, vicarious learning involves complex sequences of actions and events which complicate managerial ability to make sense of the lessons learned, leading to uncertainty around the associated strategic outcomes (Kim \& Miner, 2007). Organizational members have cognitively held beliefs and biases that influence the manner in which lessons learned are interpreted and incorporated into organizational routines. For instance, some managers may be overconfident in their skills and ability to strategize and underestimate the probability that their own organizations can fail in the market. Thus, less managerial attention is paid to the actions and outcomes of other firms. In turn, managers who have significant experience with managing failure, may become more alert to unsuccessful strategies of other firms in their industry, and allocate more managerial attention to linking actions to outcomes. Learning processes also do not always incur in the individual firm alone. Firms compete as well as collaborate, and the interactions within and between firms can constitute valuable inputs to learning (Myers, 2018) which may differ in each institutional environment in which the firm operates.

\section{A Complementary Lens for Understanding Internationalization}

As suggested in Figure 1, these three theoretical mechanisms - problemistic search, learning by doing and vicarious learning - can be used to enrich our understanding of firm decisions beyond entry mode dynamics and foreign market re-entry. Importantly, the behavioral theory of the firm can explain firm heterogeneity and firm change. The institutional characteristics of multiple goals and multiple actors mean that the goals and performance configuration of firms differ from each other, so at any one time, some firms are not engaged in problem solving while other firms are engaged in solving problems that may differ depending on the firm. An important reason for this is multiple actors, as the experience of each firm's dominant coalition of decision makers shapes their strategic decisions.

Among the theoretical mechanisms of behavioral theory, learning from own experience is especially consequential over time, because firms build experience that alters their decisions, and each firm has a unique stock of experience, leading to both firm 
change and interfirm heterogeneity. These are observable and their effects are easy to understand and predict from the behavioral theory of the firm, but they require attention to how experiences differ. Similarly, vicarious learning is a source of firm change and firm heterogeneity because the actions of others change over time, in part as a result of their learning from experience, and firms themselves differ in what firms they learn from. Again, these are observable characteristics, and their effects are easy to understand from the behavioral theory of the firm. Together, these characteristics and mechanisms can help explain a broad range of decision areas, including but not limited to those listed in Figure 1.

In the following section, we explore the relationships between individual/organizational characteristics, theoretical mechanisms and key IB decisions and highlight the value that a behavioral perspective can bring to further our understanding of internationalization behaviors.

\section{BEHAVIORAL THEORY AND INTERNATIONAL BUSINESS DECISIONS}

So, how can behavioral theory help to answer questions about MNE internationalization that cannot be answered effectively with extant theory? We identify IB strategic decisions of practical, managerial relevance, some of which have been a recurring theme in IB research (i.e., pre-internationalization decisions) and others constitute growing areas of study (i.e., post-internationalization decisions such as international market adaptation). We identify five major areas where IB scholars could benefit from using alternative insights resting in the behavioral theory of the firm: (1) the decision to internationalize; (2) nascent MNE internationalization; (3) international location choices; (4) international market adaptation; and (5) headquarter-subsidiary relationships. The list is far from comprehensive and is somewhat reflective of our own research interests, but we offer it as a guide for future inquiries and meaningful developments in the internationalization literature and its practice.

\section{Exploring the Motivations}

\section{for the Internationalization Decision}

The decision to internationalize in the first place may be accurately explained through the lens of problemistic search. Extant research has depicted internationalization as the decision of a firm endowed with superior resources and capabilities - which are assumed to constitute a source of firmspecific advantage (Caves, 1971; Hymer, 1976) - to enter new, international markets where these resources are likely to be successfully exploited, generally through high commitment operation modes (Narula, 2006; Narula \& Verbeke, 2015). Also, drawing on March (1991), Cuervo-Cazurra, Narula, and Un (2015) make an important distinction between exploitation and exploration of resources and capabilities as drivers for internationalization. However, internationalization (i.e., the decision to engage in cross-border business activities) is not something most firms do. The overwhelming majority of firms - even in small, open economies - have an exclusively domestic focus (Bonaccorsi, 1992). It seems narrow to assume that the dominant domestic focus is because all domestic firms lack a source of firm-specific advantage which they could effectively exploit in international markets. Instead, a broader view is that over time, factors in the internal and external environment of the firm change and thus, will drive some firms to internationalize, while others do not face such drivers.

The current assumption is that external, more easily measurable changes such as a decline in home market sales or increased host market attractiveness lead to internationalization (Guler \& Guillén, 2010). To explore whether changes in aspiration levels drive internationalization, we need some further research on firm goals and dynamic responses to those goals. Firms have financial goals, in which case a lack of performance below aspiration levels at home may stimulate them to look for alternative, international markets to enter. Such an internationalization motive would be consistent with the evidence on how performance below aspiration levels in financial goals such as return on investment (ROA) can lead to a broad range of strategic actions (Greve \& Gaba, 2017; Shinkle, 2012). Still, this does not fully explain the heterogeneity in firm behavior, i.e., why some firms internationalize, and many others do not. Here, we particularly disagree with the idea that the mechanisms driving internationalization - the notions of incrementalism and path dependence - have remained unchanged (Vahlne, 2020), as path dependence is not always the most relevant aspect of firm behavior and dynamism is reflected in more than incremental, stepwise decision-making.

Our question is whether inability to achieve the set sales, production, and profitability goals at 
home is what actually triggers internationalization, or whether it is changes in the goal structure (e.g., due to comparing with, and learning from, other firms) that are the main drivers to internationalize. From a behavioral theory lens, firms are expected to measure their performance in comparison to an aspiration level on a given goal. Here, current research on the behavioral theory of the firm lags behind because there is much research on firm reactions to multiple goals (Baum \& Dahlin, 2007; Gaba \& Greve, 2019), but not yet sufficient work on how firms choose their goals. The need for more research on how firms come to incorporate goals held by other firms in their peer group has been noted (Greve \& Teh, 2018), but few studies have examined what drives decision makers to set new goals to measure their organization's performance and make strategic changes. When firms create new non-financial goals, a range of new implications become possible. Importantly, internationalization may become a goal simply because top managers observe the decisions of other firms in their industry to internationalize. This is exacerbated by the fact that there are mostly positive outcomes associated with the decision to internationalize, such as enhanced reputation for the firm and individual decision makers (Thams, Alvarado-Vargas, \& Newburry, 2016). This means that, when domestic firms are exposed to the activities of more global competitors, they may alter their goals, potentially leading them to set internationalization as a new goal, which in turn may create a discrepancy between the firm's actual performance and its aspirations. Situations where performance is below aspiration levels will lead to a reassessment of organizational practices and a pr2020sity to take risks and develop remedial actions, such as directing more resources towards internationalizing (Cuervo-Cazurra et al., 2015). Over time, if performance raises above aspiration levels, it provides legitimacy and support for the MNE to engage in further internationalization activities.

Research into internationalization as an emerging goal offers a shared opportunity for researchers in IB and the behavioral theory of the firm. Casual observation suggests that internationalization does, indeed, enter the goal structure of many firms, and observation of peer firms internationalizing and reaping rewards from doing so may be an important driving force. This theoretical idea is a good match with the availability of new data and analytical methods for examining firms' goal structures, such as through text analysis of annual reports and other communications to investors.

\section{The Internationalization of Nascent MNEs}

From its inception, IB has been concerned with, and developed theory for, the traditional, large Western MNE. It is increasingly evident that firms differ in their ability to internationalize, internationalization motives and strategies (Awate, Larsen, \& Mudambi, 2012; Li \& Fleury, 2020; Narula, 2012; Sutherland, Anderson, \& Hu, 2020). The idea that internationalization is driven by firm-specific resources and capabilities that constitute an advantage in international markets often limits our understanding of internationalization to certain types of MNEs i.e., the older Western MNEs which have accumulated significant stocks of knowledge and experience over time and developed routines that often shape their internationalization. Firms with deeply embedded organizational routines are expected to absorb new knowledge accrued from experience, learn, upgrade their firm-specific advantages and make superior internationalization choices (Kogut \& Zander, 1992; Narula \& Verbeke, 2015; Santangelo \& Meyer, 2011, 2017).

Whilst the principles behind becoming an MNE (e.g., ability to compete internationally) may not have drastically changed (Narula, 2012), the international success or failure of firms does not always rest in their routines and pre-existing firm-specific advantages. Nascent multinational firms (such as born globals or emerging market multinationals) cannot rely on their international legacy or draw from a rich pool of knowledge acquired through international experience (Knight \& Liesch, 2016). Born globals - firms which internationalize fast, generally within 3 years after inception (Knight \& Cavusgil, 2004) - are relatively young and thus are unlikely to possess an organizational history or memory, or have deeply embedded routines that can be used to reduce the costs and uncertainty associated with internationalization (Mathews \& Zander, 2007). Firms originating from emerging markets may have been operating domestically for longer, but they lack international experience relative to developed market counterparts (Sutherland et al., 2020); which has led to them also being labelled as nascent (see Narula, 2012). Emerging market firms are also less likely to rely on routinebased learning as a prerequisite to internationalization. Alternative explanations build on the role of network embeddedness as a source of learning (Elango \& Pattnaik, 2007; McDermott \& 
Corredoira, 2010) or learning from other firms through engaging in cross-border mergers and acquisitions (Deng, 2009).

From a behavioral perspective, the lack of experience and knowledge generally drawn on to develop routines does not necessarily put nascent firms at a competitive disadvantage. Nascent firms likely possess other advantages, such as more flexible routines (Kumar, Singh, Purkayastha, Popli, $\&$ Gaur, 2020) that allow them to learn and repeat appropriate behaviors, whilst at the same time being able to unlearn and disregard less appropriate behaviors. This is particularly relevant in the context of constantly changing environmental demands, in that nascent firms will seek to grow internationally faster and catch up with global competitors and are thus faced with a multitude of environmental demands and opportunities to learn in each market entered (Li \& Fleury, 2020). Knowledge and experience accumulated in the past may not always provide useful routines that can aid in future internationalization endeavors such as deciding which market to expand into and which modes of operation to opt for. Changes in the host market environment may mean that firms have to disregard current knowledge and make room for new learning. Nascent MNEs are less likely to suffer from learning myopia (Levinthal \& March, 1993) and thus, may be more willing and able to make changes to their organizational practices and strategies to realign them with environmental demands. Firms that are able to weave new knowledge into their organizational routines - whether this knowledge comes from own experience or the experience of others - may be able to internationalize faster, be willing to enter and re-enter riskier markets, as well as engage in a rapid adjustment of their initial entry decisions. Importantly, we note that, by incorporating new constraints such as lack of resources, young age and myopia, and the factors needed to manage them, especially strategic flexibility and experience with trial-and-error learning, the behavioral theory of the firm could broaden the applicability of traditional models such as the Uppsala model and internalization theory to these nascent firms.

Our observations on nascent MNEs point to a research opportunity shared by researchers in IB and behavioral theory. Although firm age is recognized as an important factor in determining speed of learning (and unlearning), with younger firms being more flexible (Barnett \& Pontikes, 2008; Vermeulen \& Barkema, 2001), concerns such as data availability have led to overreliance on older firms as a research context. The main exception is the work on emerging industries, but such research is equally limited because it studies young firms, with limited variation in firm age (but see Carroll, Bigelow, Seidel, \& Tsai, 1996). When data limitations prevent comparisons that are theoretically important, such as the differences in learning behavior due to firm age and experience types, and the resulting differences in internationalization behaviors and outcomes, it is time to look for better data.

\section{MNE Location Choices}

Another important issue in IB is whether firms follow global strategies in the sense of having worldwide footprints (i.e., covering many countries in different parts of the world), or more regional strategies by concentrating on fewer markets in one or two regions (or continents). We note that this decision is different from firms' degree of internationalization per se. Firms may well be highly internationalized (measured as a ratio of foreign-tototal along some key dimension such as sales, production, assets, employees), but retain a constrained geographical footprint. The explanation for MNE location choices has been that MNEs concentrate their international activities in host locations that share similar characteristics such as similar technological infrastructures, the presence of knowledge intensive, innovative firms and relatively homogeneous demand (Rugman \& Verbeke, 2004). Again, this is often explained by industry factors, which masks substantial firm heterogeneity. An alternative explanation builds on the role of firm positions in domestic networks and on the role of absorptive capacity required to benefit from the flows of knowledge originating from these networks and use it to broaden or constrain the scope of internationalization locations (Iurkov \& Benito, 2018). Overall, scholars conclude that concentrating international operations in one or few countries or regions is beneficial for the MNE because it reduces the control and co-ordination costs associated with managing operations in dispersed markets, allowing for an overall effective resource allocation and resource management.

However, MNE location choices are idiosyncratic and vary with the firms and managers making these choices (Buckley, Devinney, \& Louviere, 2007). Indeed, there is evidence that location choices are influenced by remarkably simple sources of information availability, such as media coverage 
unrelated to the business opportunities of the location (Kulchina, 2014). The behavioral theory of the firm could provide additional understanding of international location decisions by analyzing how they are shaped by different types of experiences and routines. For instance, international location strategies may vary as a result of MNEs being able to draw from repetitive compared to more flexible organizational routines. To the extent that a firm operates in multiple markets, it is more likely to consider those markets which are similar to one another and thus, which enable utilization of existing knowledge (about customers, competitors) and routines (about what strategies work and do not work in the market). Hence, a typical expectation in international business is that firms will, all else equal, tend to start their internationalization in markets that are close and similar to their home market (Johanson \& Vahlne, 1977). The "all else equal" condition is key, however, as such decisions are also affected by other factors such as the motivation - or economic rationale - for the international venture, which delimits the feasible set of location alternatives. For example, Norwegian firms seeking low cost locations for their manufacturing may have to search for viable sites in nations that are at considerable distance however measured -, simply because nearby nations also have high cost. Still, as demonstrated by Benito and Gripsrud (1992), even if the initial location decisions entail a significant step in terms of distance, firms tend to favor host countries nearby the initial entry when making subsequent foreign entries, thereby taking advantage of existing and transferable knowledge.

Indeed, repetitive routines may reduce the costs associated with learning about different markets. There is evidence that firms apply learning both from own experience and from the experience of peer firms when choosing location choices for internationalization (Bastos \& Greve, 2003). Yet, learning is considered most effective - but also most challenging - when experience acquired in one market can be transferred into a different, more distant market location (Eriksson, Johanson, Majkgård, \& Sharma 1997). As Pedersen and Shaver (2011, p. 273) remark "the first step is the most difficult and demanding"; the time and resources initially spent on developing internationalization competence and routines is an investment that enables further steps abroad. Here, we suggest that flexible routines may enable MNEs to use knowledge acquired from experience in one market location into another market location. Furthermore, the experience and intentions of the managers may influence how choice attributes associated with each international location are weighed; a market can be characterized by high growth and high investment potential (allowing for the exploitation of firm-specific resources), but also high risks such as political instability and poor protection of intellectual property rights.

An important and relatively more recent development in behavioral theory is exploration of how decision makers (e.g., managers and board members) are shaped by their experience, which makes firm choices a function of coalition building among decision makers with shared experience and expertise (Zhang \& Greve, 2019). It follows that high-risk conditions may deter less internationally experienced managers but not managers (and board members) with international experience. In turn, inexperienced managers may be less deterred by entering stable markets, even if they require a high level of adaptation or even changes to the MNE's business model. We note recent efforts to better understand the roles of managerial intentionality and experience in internationalization (Dow, Liesch, \& Welch, 2018; Hutzschenreuter, Pedersen, $\&$ Volberda, 2007) and encourage more research on this topic.

\section{International Market Adaptation}

Another IB behavior on that can be examined through the lens of behavioral theory is whether firms deploy their business models unchanged as they move into new international markets or adapt them to specific local market conditions. The prevailing view in IB and strategy is that such decisions are largely driven by external factors, such as industry characteristics - some industries are more amenable to standardized solutions, for example consumer electronics, whereas other industries favor localized solutions, such as legal services - and country characteristics such as host market legislation, culture, norms and customs (Bartlett \& Ghoshal, 1989; Ghemawat, 2007; Yip, 1989).

Despite the influence of external factors, there is considerable firm heterogeneity within industries and countries (Nachum \& Song, 2011). Such heterogeneity suggests that internal rules and routines better explain firm behavior than external, contextual factors (Jensen \& Szulanski, 2004; Papadakis, Lioukas, \& Chambers, 1998). A useful way of thinking about home-host country 
differences is that firms learn from some contexts, mainly their home country and earliest internationalization experiences, and seek to apply this knowledge in each new entry. External factors introduce tensions, but such tensions alone do not explain behavior. Firms need to learn about the problems resulting from the external factors of each new location, and subsequently find solutions to these problems. This is another application of problemistic search theory, indicating that a behavioral view of the MNE would offer a much-needed firm-level explanation that accounts for the heterogeneity in international market adaptation strategies. Although early internationalization research (Johanson \& Vahlne, 1977) defined local market adaptation as a distinct form of market commitment, later research mostly focused on the amount of resources committed to internationalization, which is the easy-to-grasp and simple-to-measure side of market commitment.

Here, we propose that the extent to which firms adapt will depend on their ability to recognize the need for, and implement, adaptive strategies. By observing industry and country factors, researchers have focused on the objective outcomes of adaptation strategies, i.e., to adapt or not to adapt (with best performers being the ones who effectively adapt) but failed to understand the process of searching for solutions to problems which originate internally. From a behavioral perspective, performance below aspiration levels will trigger firms to engage in problemistic search and look for alternative strategies to serve the host market. A central part of such research is to correctly understand the firm's goals. Although a firm will always have profitability or ROA as a goal, its presence in an international market may have other objectives. Chinese consumer electronics companies now seeking to enter (and for some, re-enter) the U.S. market are a good example of multiple goals. These companies associate globalness with operating in the U.S. market, despite the need to adapt to local regulation, overcome trade barriers, and manage the country-of-origin reputation disadvantages - all to enter an already highly saturated market. It is evident a priori that the required local market adaptations threaten their low-cost business model and reduce their profitability. However, adapting to the U.S. market is consistent with an overarching goal of becoming global like their developed market counterparts (i.e., the firm-level goal), whilst their decision makers may attribute a presence in the attractive U.S. market to their own knowledge and expertise (i.e., individual-level goal). Such market entries cannot be explained by profit maximization and exploitation of firm competitive advantages logics, but they become easier to understand when seeing each firm as having multiple goals.

In order to successfully adapt to already entered international markets, the causes of why firms have performed below their aspiration levels also need to be well understood. When uncertainty associated with effectively serving the market becomes significant, firms seek coping mechanisms that may help them anticipate market changes. These are often rooted in the firm's past experiences, e.g., experience with market adaptation failure and solutions identified to manage it. Furthermore, adaptation choices come from learning processes which, over time, develop into routines. Organizations with fewer resources are more likely to look for familiar solutions to problems than organizations with significant resources (which may exploit solutions that come from untested strategic repertoires).

Firm learning, and subsequent behavioral changes, such as changes in strategy to adapt to an international market, do not occur in a vacuum. Learning vicariously, i.e., by observing the actions of other market players (intentionally or unintentionally) may constitute a less resource-intensive form of knowledge acquisition (Kim \& Miner, 2007). Observation may be a strong driver of behavioral changes (Bandura, 1977), as managers can learn from observing the actions and consequences of such actions on other firms, without having to directly experience the feedback themselves. This may teach firms about forms of market adaptations that lead to negative consequences, and thus should be avoided; for example, choosing a product name that may be offensive to local customers. In turn, firms may seek to replicate successful behaviors. At the same time, when first mover advantages are important, observational learning may lead to firms being late to implement market adaptations.

Since MNEs operate in dynamic environments, over time, they are expected to adapt their goals and aspirations. A comprehensive understanding of international market adaptation mechanisms would require an understanding of firm behavior in relation to environmental feedback. When the level of ambiguity around the outcomes of environmental changes increases, it may become difficult to understand the extent to which past decisions are applicable to new contexts; thus, 
cause and effect linkages become difficult to establish (Levitt \& March, 1988). Managers may find it more difficult to assess the performance of past experiences and their usefulness. Longitudinal studies are useful to capture firm decisions at different points in time and analyze them in relation to changes in the environment of the firm. We conjecture that heterogeneity of experiences (learning from own experiences and from vicarious learning) would lead to more successful and timely market adaptation in constantly changing host environmental contexts.

\section{Headquarter-Subsidiary Relationships}

Much of the literature on headquarter-subsidiary relationships has focused on the position of the subsidiary within the MNE (Benito, Grøgaard, \& Narula, 2003; Birkinshaw \& Pedersen, 2010), to explain how an international subsidiary can acquire deep knowledge about its local environment (e.g., knowledge about customers, competitors, business partners) and transfer this knowledge to sister subsidiaries and the MNE headquarters (Andersson, Forsgren, \& Holm, 2001, 2007; Foss \& Pedersen, 2004; Meyer, Mudambi, \& Narula, 2011). A positive impact is generally expected between a subsidiary becoming embedded in its network of customers and suppliers, its competence development and the transfer of such competences which are likely to become a source of competitive advantage for the MNE (Andersson et al., 2001; Dhanaraj, Lyles, Steensma, \& Tihanyi, 2004; Håkanson \& Nobel, 2001). In practice, MNEs do not always have strong, complementary ties with their subsidiaries (Verbeke, 2009); it is unsurprising that these relationships do not always result in effective knowledge creation and knowledge transfer.

We propose that, a complementary explanation to headquarter-subsidiary relationship management may be achieved through a behavioral lens. Our rationale is that, in practice, international subsidiaries engage in the pursuit of multiple goals, beyond those related to achieving high profitability. Subsidiaries take initiatives (Birkinshaw \& Pedersen, 2010), and may set their goals around local market legitimacy, status, market growth, or desired position in the corporate hierarchy (Lunnan, Tomassen, Andersson, \& Benito, 2019). The MNE headquarters also has goals, however, and aspiration levels for each goal and each subsidiary. Some subsidiary goals may conflict with the goals set out by MNE headquarters, and even when goals are shared, headquarters and subsidiary may have divergence in judgement (Lunnan et al., 2019) concerning the effects of market forces and the best courses of action. The result is conflict around goals and aspiration levels, as well as levels of acceptable risk. There is evidence that headquarter-subsidiary goal conflicts exist and are resolved to the advantage of the subsidiary when the subsidiary is more powerful relative to the headquarter (Gaba \& Joseph, 2013).

Power use is not the only way that the subsidiary can influence this process and resolve the conflict between its goals and aspiration levels and those of headquarters. For instance, subsidiaries may choose to withhold knowledge about the local market to avoid losing their competitive edge and position within the MNE network (Lunnan et al., 2019); this may be the case even when such knowledge would constitute a source of competitive advantage for the MNE or other sister subsidiaries. This may be more probable when profitability and or market share fall below the aspiration levels and subsidiaries require resources in order to understand, and adapt to, the local environment in order to preserve their own position in the market; as such, less resources will be allocated to the transfer of knowledge to headquarters (at least in the short term). Satisfaction of subsidiary goals may come at the expense of satisfaction of MNE goals (which may not always be financial performance-related for each subsidiary), which complicates the process of prioritizing goals and searching for solutions to problems particularly when performance falls below aspiration levels. Subsidiary relationship management is likely to require the MNE to resolve conflict through temporary compromises between differing goals. Resolving such conflicts is of significant importance (Ethiraj \& Levinthal, 2009), especially for multi-unit firms such as MNEs. Coalitions can be used to resolve conflicts and choose amongst alternative goals.

A behavioral perspective - focusing on the process by which headquarters resolve their conflicts with their subsidiaries - takes us beyond the takenfor-granted, static view of MNEs and their subsidiaries operating in a hierarchical structure. Even for goals that are replicated on a smaller scale at the subsidiary level, such as ROA, it is not obvious what the aspiration levels will be and how the subsidiary or headquarter will react to them. For instance, MNE headquarters may design performance goals (and incentives) that relate specifically to knowledge transfer - of operations to a new subsidiary, 
and of consumer preferences back to headquarters. Such an understanding would better reflect business practice by capturing how and under what conditions MNE headquarters and subsidiaries are more or less likely to reduce their goals to common dimensions, thus alleviating some of the bounded rationality challenges. The concept of bounded reliability (Verbeke \& Greidanus, 2009) has been proposed to explain how actors inside the MNE select and prioritize different facets of information in order to make biased decisions, which, in turn, triggers conflicts such as those between MNEs and their subsidiaries. Naturally, actors' goals change over time in relation to environmental feedback (Verbeke \& Greidanus, 2009), which will then require a renegotiation of those goals.

Table 1 below summarizes the differences in some of the key assumptions of traditional and behavioral perspectives around the internationalization-related decisions discussed.

\section{DISCUSSION}

IB has learned extensively about firm internationalization from traditional theoretical perspectives, but there is more to learn about international firms, especially given the heterogeneity observed in their behaviors over the years. We encourage scholars to deviate from relying primarily on traditional models and theories of internationalization, because these theories and models have been developed to examine different behaviors unfolding in a different time. Given the increased pressures for firms to perform under conditions of change and uncertainty and their - often conflicting - strategic goals, we believe this to be an opportune time to enrich our way of thinking, and theorizing, about the international firm.

We also encourage scholars in IB and other areas of management research to increase the joint development of theory and evidence. Many firms are international, but scholars in organizational theory and strategic management rarely distinguish international firms from firms that are mainly or fully domestic. Much theory and evidence in organizational theory and strategic management is drawn from investigation of international firms, but scholars in IB often fail to recognize this connection. Undoubtedly, scholars in each of these parallel fields understand these connections and wish to transfer knowledge. The problem is that divergence of theories complicate communications among the fields. Theories that are broadly used in each field are useful because the evidence generated translates easily from field to field, thus creating a common language between scholarly contributions. Our argument - an increased collaboration between IB and other areas of management research - favors using any theory that is widespread and crosses fields of investigation, and we raise it here because the behavioral theory of the firm has been, and continues to be used in both organizational theory and strategic management, with researchers in both fields fully aware of, and building upon, the progress done in the other.

Applying a theory to a field always offers the potential to enrich it. A theory provides a lens and a magnifying glass that allows us to examine a firm behavior and explain it in more detail. It adds details and focus at the cost of explaining the behavior from a narrower perspective. This is why behaviors of any complexity can be fruitfully studied by more than one theory, and it is also why a theory of reasonable parsimony cannot fully explain behaviors of any complexity. Existing IB theories and models may therefore provide the starting point to which we add to gain a more nuanced understanding of current internationalization behaviors. That is the rationale behind proposing a complementary theoretical perspective rooted in the behavioral theory of the firm. We are advocates of the behavioral perspective because it captures what has been often either overlooked or insufficiently emphasized in past studies - the importance of perceived performance, the recognition of multiple (individual and firm) goals and how these may not always align, the role of coalitions in reconciling multiple goals, and the importance of different types of learning. In doing so, behavioral theory enables a relevant understanding of how MNEs strategize and welcomes examination of firm change and heterogeneity. Thus, the behavioral theory of the MNE provides a suitable foundation to add to our understanding of internationalization-related choices as well as add to, and enrich, traditional models and theories.

In our view, at least two main contributions arise from our proposed behavioral approach. First, the behavioral theory can help to answer questions about firm internationalization that cannot be answered effectively with extant theory. We started our discussion with two key IB behaviors which have remained under-explained due to the limitations of traditional approaches: multi-mode entries and international market re-entry after previous exit. One of the explanations for this lack of 


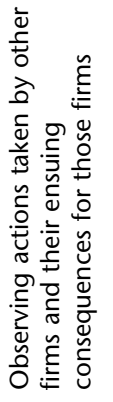

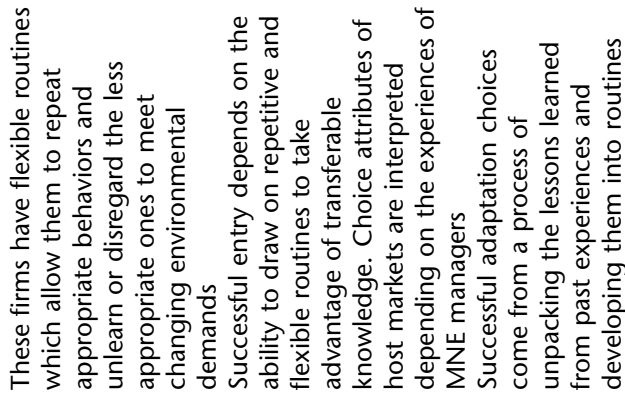
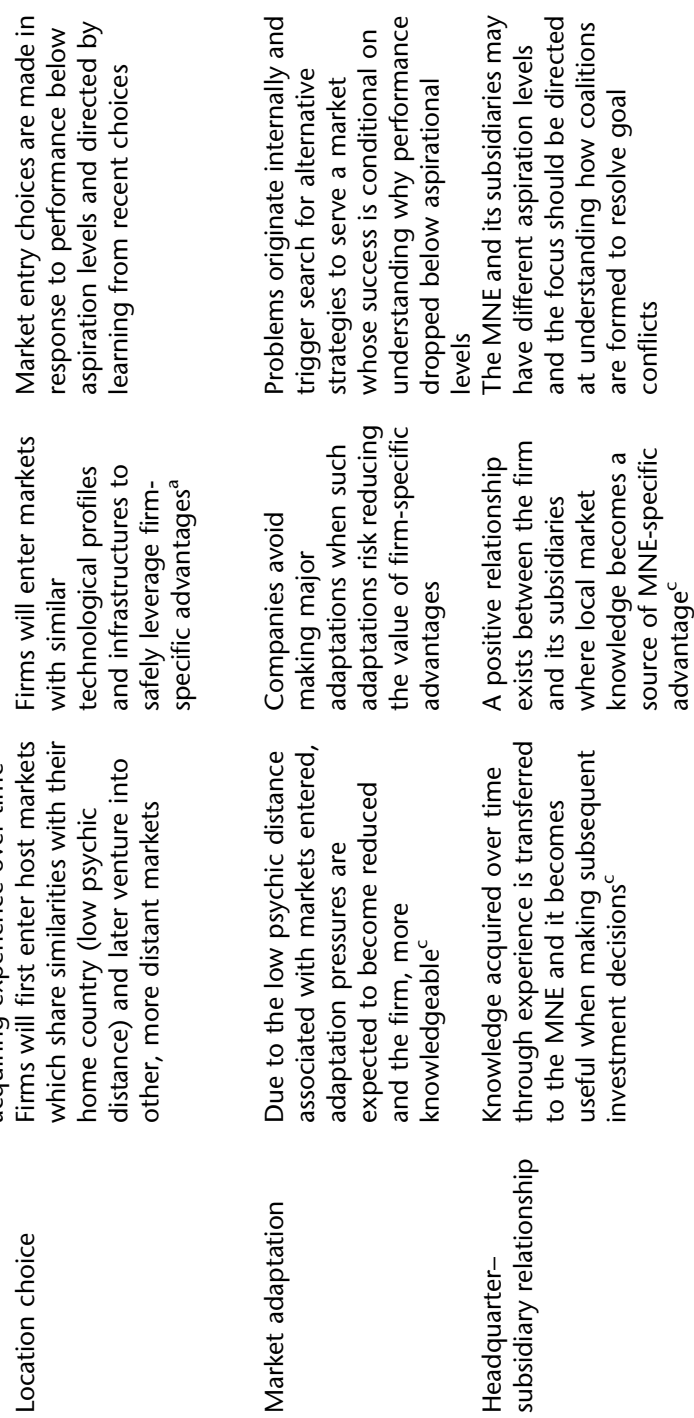

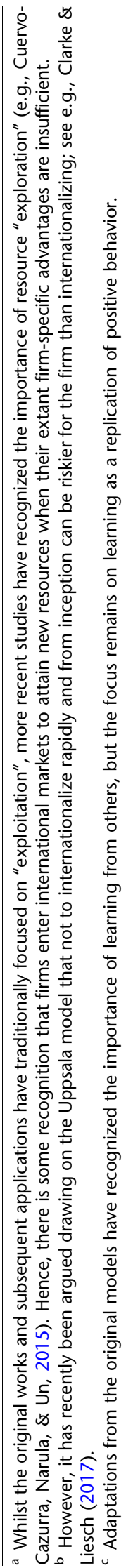


research - despite the empirical evidence that MNEs are often confronted with such strategic choices - has been the poor translation of traditional models. Incremental insights and contributions at the edge of established theories - a practice often associated with scientific rigor - are, however, insufficient to explain why firms decide to combine multiple modes of entry into an international market and switch between them. From a learning perspective, operating multiple modes puts a strain on the firm, which then needs to make adjustments to convert knowledge acquired from one type of experience into knowledge useful to utilize in other choice contexts.

In the same way, traditional models should account for firms choosing to divest from, and reenter into, international markets. From the perspective of problemistic search, re-entry may be explained by understanding how firms frame the market exit experience and whether such a market setback weakens collations associated with internationalization (resulting in re-allocating resources). Further, how the initial entry experience is retrieved, interpreted and embedded into different types of routines influences whether firms repeat past behaviors or adapt by incorporating new strategies in their repertoires. Complex and dynamic MNE choices should not be viewed merely as an opportunity for theoretical testing (Buckley et al., 2017); rather, we should seek to provide them with their own identity.

Our second contribution is that we explain how the behavioral theory fits with what we already know about some of the most studied internationalization decisions, and how we can extend this knowledge to enrich our theorizing. As we expand our examination beyond multi-mode and re-entry strategies, in each line of research, we found areas of investigation that could be opened by applying a behavioral lens more rigorously. Addressing the second question - how does behavioral theory fit with what we already know? - as shown in Table 1, internationalization research so far can be placed side by side with our proposed theoretical mechanisms from the behavioral theory of the firm. This comparison shows that a richer view of each process is reached by considering both jointly. Accordingly, this paper theorizes on the impact of problemistic search and organizational learning on five main internationalization decisions: (1) the decision to internationalize; (2) nascent MNE internationalization; (3) international location choices; (4) international market adaptation; and
(5) headquarter-subsidiary relationships. We discuss how, so far, the decision to internationalize is often explained in terms of the push to escape a declining home market and utilize firm-specific advantages. Even so, firm behavior is far less rational than that and much more influenced by individual and firm-level goals (Buckley et al., 2007; Puig et al., 2020). These goals may in turn be heterogeneous across firms and lead to specific aspiration levels which, when not met at a given point in time, may drive a change in firm behavior such as the decision to internationalize. Other decisions, such as where and when, are shaped by the problem the firm seeks to solve, its own experience with similar decisions, along with vicarious learning. In the same way, once firms enter international markets, they need to constantly search for strategies to serve those markets through their international subsidiaries, which, more often than not, develop their own goals and aspirations around what constitutes best performance. Understanding the dynamics of subsidiary management through new theoretical lenses such as behavioral theories, has recently been placed at the forefront of the IB research agenda (see Meyer, Li, \& Schotter, 2020).

Further, we emphasize the importance of organizational learning as a key mechanism of behavioral theory, which goes beyond acquiring and using experiential knowledge to enter, and increase commitment in, nearby international markets. International location choices are not merely a function of entering similarly advanced host markets where firm-specific advantages can be utilized, in that firms enter foreign markets depending on their strategic motivations; as well as their ability to draw on flexible routines to use experience acquired in one market location into another. This may be more so for nascent internationalizers, who are less likely to suffer from learning myopia and who may better adapt their learning base and routines to changing internal goals and external contexts. Traditional models such as internalization theory and the Uppsala model would benefit from integrating behavioral insights more rigorously, in order to discuss decision alternatives in response to strategic problems and changes in the environments of firms, not necessarily strategic opportunities at a given point in time.

In summary, drawing on the behavioral theory of the firm makes sense of under-explained IB behaviors. Using the behavioral theory of the firm can produce distinctive and managerially relevant 
insights on firm internationalization. This, we believe, captures the essence of our discussion.

\section{CONCLUSION}

While research on internationalization has developed well in the past, as with any established field of study, there are opportunities to rejuvenate it. As this discussion has shown, the behavioral theory of the firm is sufficiently general that it can be used to examine multiple firm behaviors of interest to IB scholars. In each case, the theory seems easily applicable, predictions follow naturally, and empirical investigation is needed in order to discover the existence and strength of the effects. Research on internationalization decisions and their consequences has a long and distinguished track record, but this does not mean that it is time to stop, or that there is no room for complementary ideas and new evidence. In fact, we see broad areas of opportunity opening from applying additional theoretical lenses, and we believe the behavioral theory of the firm is a great place to start.

\section{ACKNOWLEDGEMENTS}

We thank Rajneesh Narula for his effective and supportive editorial guidance during the review process as well as two anonymous reviewers for their insightful and valuable comments. We thank Øivind Revang for his helpful comments on an earlier version of this manuscript. The authors are listed in reverse alphabetical order.

\section{NOTE}

${ }^{1}$ This perspective piece focuses specifically on how a behavioral theory of the firm adds to what we already know about firm internationalization. We do not focus on its outgrowth, organizational learning theory because the latter constitutes a larger group of theories (including learning curves, organizational memory, capability development, and so on). We are aware that such reasoning has been used in IB with some studies already drawing broadly on organizational learning. As such, we explicitly called for the behavioral theory of the firm because that is the part that is missing most, although it is prominent elsewhere in the management field.

\section{REFERENCES}

Aguzzoli, R., Lengler, J., Sousa, C. M. P., \& Benito, G. R. G. 2020. Here we go again: A case study on re-entering a foreign market. British Journal of Management. https://doi.org/10. 1111/1467-8551.12407.

Aharoni, Y. 1966. The foreign investment decision process. Cambridge, MA: Harvard University Press.

Aharoni, Y., Tihanyi, L., \& Connelly, B. L. 2011. Managerial decision-making in international business: A forty-five-year retrospective. Journal of World Business, 46(2): 135-142.

Anand, B. N., \& Khanna, T. 2000. Do firms learn to create value? The case of alliances. Strategic Management Journal, 21(3): 295-315.

Anderson, E., \& Gatignon, H. 1986. Modes of foreign entry: A transaction cost analysis and propositions. Journal of International Business Studies, 17(3): 1-26.

Andersson, U., Forsgren, M., \& Holm, U. 2001. Subsidiary embeddedness and competence development in MNCs a multi-level analysis. Organization Studies, 22(6): 1013-1034.

Andersson, U., Forsgren, M., \& Holm, U. 2007. Balancing subsidiary influence in the federative MNC: A business network view. Journal of International Business Studies, 38(5): 802-818.

Arikan, I., \& Shenkar, O. 2013. National animosity and crossborder alliances. Academy of Management Journal, 56(6): 1516-1544.

Awate, S., Larsen, M. M., \& Mudambi, R. 2012. EMNE catch up strategies in the wind turbine industry: Is there a trade-off between output and innovation capabilities? Global Strategy Journal, 2(3): 205-223.

Bandura, A. 1977. Social learning theory. Englewood Cliffs, NJ: Prentice-Hall.

Barkema, H. G., \& Schijven, M. 2008. Toward unlocking the full potential of acquisitions: The role of organizational restructuring. Academy of Management Journal, 51(4): 696-722.

Barkema, H. G., Shenkar, O., Vermeulen, F., \& Bell, J. H. J. 1997. Working abroad, working with others: How firms learn to operate international joint ventures. Academy of Management Journal, 40(2): 426-442.

Barnett, W. P., \& Pontikes, E. G. 2008. The red queen, success bias, and organizational inertia. Management Science, 54(7): 1237-1251.

Bartlett, C. A., \& Ghoshal, S. 1989. Managing across borders: The transnational solution. Cambridge, MA: Harvard Business Press.

Bastos, P. V., \& Greve, H. R. 2003. Interorganizational learning and the location of manufacturing subsidiaries: Is chain migration also a corporate behavior? Advances in Strategic Management, 20, 159-191.

Baum, J. A. C., \& Dahlin, K. B. 2007. Aspiration performance and railroads' patterns of learning from train wrecks and crashes. Organization Science, 18(3): 368-385.

Becker, M. C. (Ed.). 2008. Handbook of organizational routines. Cheltenham: Edward Elgar.

Benito, G. R. G., \& Gripsrud, G. 1992. The expansion of foreign direct investments: Discrete rational location choices or a 
cultural learning process? Journal of International Business Studies, 23(3): 461-476.

Benito, G. R. G., Grøgaard, B., \& Narula, R. 2003. Environmental influences on MNE subsidiary roles: Economic integration and the Nordic countries. Journal of International Business Studies, 34(5): 443-456.

Benito, G. R. G., Petersen, B., \& Welch, L. S. 2009. Towards more realistic conceptualisations of foreign operation modes. Journal of International Business Studies, 40(9): 1455-1470.

Benito, G. R. G., Petersen, B., \& Welch, L. S. 2011. Mode combinations and international operations: Theoretical issues and an empirical investigation. Management International Review, 51(6): 803-820.

Benito, G. R. G., Petersen, B., \& Welch, L. S. 2021. Dynamics of operation modes: Switches and additions. In K. Mellahi, K. Meyer, R. Narula, I. Surdu, \& A. Verbeke (Eds.): The Oxford handbook of international business strategy. Oxford: Oxford University Press.

Benito, G. R. G., \& Welch, L. S. 1997. De-internationalization. Management International Review, 37(SI 2): 7-25.

Birkinshaw, J. M., \& Pedersen, T. 2010. Strategy and management in MNE subsidiaries. In A. M. Rugman (Ed.): The Oxford handbook of international business (2nd ed.). Oxford: Oxford University Press.

Bonaccorsi, A. 1992. On the relationship between firm size and export intensity. Journal of International Business Studies, 23(4): 605-635.

Bromiley, P., \& Harris, J. D. 2014. A comparison of alternative measures of organizational aspirations. Strategic Management Journal, 35(3): 338-357.

Brouthers, K. D., \& Hennart, J.-F. 2007. Boundaries of the firm: Insights from international entry mode research. Journal of Management, 33(3): 395-425.

Buckley, P. J., \& Casson, M. C. 1976. The future of multinational enterprise. London: Macmillan.

Buckley, P. J., Devinney, T. M., \& Louviere, J. J. 2007. Do managers behave the way theory suggests? A choice-theoretic examination of foreign direct investment location decisionmaking. Journal of International Business Studies, 38(7): 1069-1094.

Buckley, P. J., Doh, J., \& Benischke, M. 2017. Towards a renaissance in international business research? Big questions, grand challenges, and the future of IB scholarship. Journal of International Business Studies, 48(9): 1045-1064.

Carroll, G. R., Bigelow, L. S., Seidel, M.-D., \& Tsai, L. B. 1996. The fates of de novo and de alio producers in the American automobile industry 1885-1981. Strategic Management Journal, 17(Summer Special Issue): 117-137.

Casillas, J. C., Barbero, J. L., \& Sapienza, H. J. 2015. Knowledge acquisition, learning, and the initial pace of internationalization. International Business Review, 24(1): 102-114.

Casson, M. 1999. The organisation and evolution of the multinational enterprise: An information cost approach. Management International Review, 39(1): 77-121.

Casson, M. 2000. Economics of international business: $A$ new research agenda. Cheltenham: Edward Elgar.

Caves, R. E. 1971. International corporations: The industrial economics of foreign investment. Economica, 38(149): 1-27.

Chang, S.-J., \& Rosenzweig, P. M. 2001. The choice of entry mode in sequential foreign direct investment. Strategic Management Journal, 22(8): 777-792.

Clark, T., Pugh, D. S., \& Mallory, G. 1997. The process of internationalization in the operating firm. International Business Review, 6(6): 605-623.

Clarke, J. E., \& Liesch, P. W. 2017. Wait-and-see strategy: Risk management in the internationalization process model. Journal of International Business Studies, 48(8): 923-940.

Collinson, S., \& Narula, R. 2014. Asset recombination in international partnerships as a source of improved innovation capabilities in China. Multinational Business Review, 22(4): 394-417.
Compagni, A., Mele, V., \& Ravasi, D. V. 2015. How early implementations influence later adoptions of innovation: Social positioning and skill reproduction in the diffusion of robotic surgery. Academy of Management Journal, 58(1): 242-278.

Cuervo-Cazurra, A., Narula, R., \& Un, C. A. 2015. Internationalization motives: Sell more, buy better, upgrade and escape. Multinational Business Review, 23(1): 25-35.

Cyert, R. M., \& March, J. G. 1963. A behavioral theory of the firm. Englewood Cliffs, NJ: Prentice-Hall.

Dekker, H. C., \& van den Abbeele, A. 2010. Organizational learning and interfirm control: The effects of partner search and prior exchange experiences. Organization Science, 21(6): 1233-1250.

Delios, A. 2017. The death and rebirth (?) of international business research. Journal of Management Studies, 54(3): 391-397.

Deng, P. 2009. Why do Chinese firms tend to acquire strategic assets in international expansion? Journal of World Business, 44(1): 74-84.

Denrell, J. 2003. Vicarious learning, undersampling of failure, and the myths of management. Organization Science, 14(3): 227-243.

Dhanaraj, C., Lyles, M. A., Steensma, H. K., \& Tihanyi, L. 2004. Managing tacit and explicit knowledge transfer in IJVs: The role of relational embeddedness and the impact on performance. Journal of International Business Studies, 35(5): 428-442.

Dow, D., Liesch, P., \& Welch, L. 2018. Inertia and managerial intentionality: Extending the Uppsala model. Management International Review, 58(3): 465-493.

Duysters, G., Lavie, D., Sabidussi, A., \& Stettner, U. 2019. What drives exploration? Convergence and divergence of exploration tendencies among alliance partners and competitors. Academy of Management Journal. https://doi.org/10.5465/ amj.2017.1409.

Elango, B., \& Pattnaik, C. 2007. Building capabilities for international operations through networks: A study of Indian firms. Journal of International Business Studies, 38(4): 541-555.

Eriksson, K., Johanson, J., Majkgård, A., \& Sharma, D. D. 1997. Experiential knowledge and costs in the internationalization process. Journal of International Business Studies, 28(2): 337-360.

Ethiraj, S. K., \& Levinthal, D. 2009. Hoping for A to Z while rewarding only A: Complex organizations and multiple goals. Organization Science, 20(1): 4-21.

Feldman, M. S. 2000. Organizational routines as a source of continuous change. Organization Science, 11(6): 611-629.

Feldman, M. S., \& Pentland, B. T. 2003. Reconceptualizing organizational routines as a source of flexibility and change. Administrative Science Quarterly, 48(1): 94-118.

Foss, N. J., \& Pedersen, T. 2004. Organizing knowledge processes in the multinational corporation: An introduction. Journal of International Business Studies, 35(5): 340-349.

Foss, N. J., \& Weber, L. 2016. Moving opportunism to the back seat: Bounded rationality, costly conflict, and hierarchical forms. Academy of Management Review, 41(1): 61-79.

Gaba, V., \& Greve, H. R. 2019. Safe or profitable? The pursuit of conflicting goals. Organization Science, 30(4): 647-667.

Gaba, V., \& Joseph, J. 2013. Corporate structure and performance feedback: Aspirations and adaptation in M-form firms. Organization Science, 24(4): 1102-1119.

Gavetti, G., Greve, H. R., Levinthal, D. A., \& Ocasio, W. 2012. The behavioral theory of the firm: Assessment and prospects. Academy of Management Annals, 6, 1-40.

Ghemawat, P. 2007. Managing differences: The central challenge of global strategy. Harvard Business Review, 85(3): 58-68.

Gong, Y., Zhang, Y., \& Xia, J. 2019. Do firms learn more from small or big successes and failures? A test of the outcome- 
based feedback learning perspective. Journal of Management, 45(3): 1034-1056.

Greve, H. R. 1998. Performance, aspirations, and risky organizational change. Administrative Science Quarterly, 44(1): $58-86$.

Greve, H. R. 2003. A behavioral theory of R\&D expenditures and innovation: Evidence from shipbuilding. Academy of Management Journal, 46(6): 685-702.

Greve, H. R. 2008. A behavioral theory of firm growth: Sequential attention to size and performance goals. Academy of Management Journal, 51(3): 476-494.

Greve, H. R. 2009. Bigger and safer: The diffusion of competitive advantage. Strategic Management Journal, 30(1): 1-23.

Greve, H. R., \& Gaba, V. 2017. Performance feedback in organizations and groups: Common themes. In L. Argote \& J. Levine (Eds.): The Oxford handbook of group and organizational learning. Oxford: Oxford University Press.

Greve, H. R., \& Teh, D. 2018. Goal selection internally and externally: A behavioral theory of institutionalization. International Journal of Management Reviews, 20, S19-S38.

Gulati, R., Lavie, D., \& Singh, H. 2009. The nature of partnering experience and the gains from alliances. Strategic Management Journal, 30(11): 1213-1233.

Guler, I., \& Guillén, M. F. 2010. Institutions and the internationalization of US venture capital firms. Journal of International Business Studies, 41(2): 185-205.

Håkanson, L., \& Nobel, R. 2001. Organizational characteristics and reverse technology transfer. Management International Review, 41(4): 395-420.

Haleblian, J., Kim, J.-Y. J., \& Rajagopalan, N. 2006. The influence of acquisition experience and performance on acquisition behavior: Evidence from the U.S. commercial banking industry. Academy of Management Journal, 49(2): 357-370.

Hambrick, D. C., Cho, T. S., \& Chen, M.-J. 1996. The influence of top management team heterogeneity on firms' competitive moves. Administrative Science Quarterly, 41(4): 659-684.

Hambrick, D. C., \& Mason, P. A. 1984. Upper echelons: The organization as a reflection of its top managers. Academy of Management Review, 9(2): 193-206.

Haunschild, P., \& Miner, A. 1997. Modes of interorganizational imitation: The effects of outcome salience and uncertainty. Administrative Science Quarterly, 42(3): 472-500.

Hennart, J. F. 1982. A theory of the multinational enterprise. Ann Arbor, MI: University of Michigan Press.

Hutzschenreuter, T., Pedersen, T., \& Volberda, H. W. 2007. The role of path dependency and managerial intentionality: A perspective on international business research. Journal of International Business Studies, 38(7): 1055-1068.

Hymer, S. H. 1976. The international operations of national firms. Boston, MA: MIT Press.

Ingram, P., \& Baum, J. A. C. 1997. Opportunity and constraint: Organizations' learning from the operating and competitive experience of industries. Strategic Management Journal, 18(Summer Special Issue): 75-98.

lurkov, V., \& Benito, G. R. G. 2018. Domestic alliance networks and regional strategies of MNEs: A structural embeddedness perspective. Journal of International Business Studies, 49(8): 1033-1059.

Jensen, R., \& Szulanski, G. 2004. Stickiness and the adaptation of organizational practices in cross-border knowledge transfers. Journal of International Business Studies, 35(6): 508-523.

Johanson, J., \& Vahlne, J.-E. 1977. The internationalization process of the firm-A model of knowledge development and increasing foreign market commitments. Journal of International Business Studies, 8(1): 23-32.

Johanson, J., \& Vahlne, J.-E. 2009. The Uppsala internationalization process model revisited: From liability of foreignness to liability of outsidership. Journal of International Business Studies, 40(9): 1411-1431.
Jung, J. C., \& Bansal, P. 2009. How firm performance affects internationalization. Management International Review, 49(6): 709-732.

Kim, J., \& Miner, A. S. 2007. Vicarious learning from the failures and near-failures of others: Evidence from the U.S. commercial banking industry. Academy of Management Journal, 50(3): 687-714.

Knight, G. A., \& Cavusgil, S. T. 2004. Innovation, organizational capabilities, and the born-global firm. Journal of International Business Studies, 35(2): 124-141.

Knight, G. A., \& Liesch, P. W. 2016. Internationalization: From incremental to born global. Journal of World Business, 51(1): 93-102.

Kogut, B., \& Zander, U. 1992. Knowledge of the firm, combinative capabilities, and the replication of technology. Organization Science, 3(3): 383-397.

Kotiloglu, S., Chen, Y., \& Lechler, T. 2019. Organizational responses to performance feedback: A meta-analytic review. Strategic Organization. https://doi.org/10.1177/ 1476127019883361.

Kulchina, E. 2014. Media coverage and location choice. Strategic Management Journal, 35(4): 596-605.

Kumar, V., Singh, D., Purkayastha, A., Popli, M., \& Gaur, A. 2020. Springboard internationalization by emerging market firms: Speed of first cross-border acquisition. Journal of International Business Studies, 51(2): 172-193.

Kuusela, P., Keil, T., \& Maula, M. 2017. Driven by aspirations, but in what direction? Performance shortfalls, slack resources, and resource-consuming vs. resource-freeing organizational change. Strategic Management Journal, 38(5): 1101-1120.

Lavie, D., Kang, J., \& Rosenkopf, L. 2011. Balance within and across domains: The performance implications of exploration and exploitation in alliances. Organization Science, 22(6): 1517-1538.

Lavie, D., Stettner, U., \& Tushman, M. L. 2010. Exploration and exploitation within and across organizations. Academy of Management Annals, 4, 109-155.

Levinthal, D. A., \& March, J. G. 1993. The myopia of learning. Strategic Management Journal, 14(Winter Special Issue): 95-112.

Levitt, B., \& March, J. G. 1988. Organizational learning. Annual Review of Sociology, 14, 319-338.

Li, J. T., \& Fleury, M. T. L. 2020. Overcoming the liability of outsidership for emerging market MNEs: A capability-building perspective. Journal of International Business Studies, 51(1): 23-37.

Lunnan, R., Tomassen, S., Andersson, U., \& Benito, G. R. G. 2019. Dealing with headquarters in the multinational corporation: A subsidiary perspective on organizing costs. Journal of Organization Design, 8: article 12.

March, J. G. 1991. Exploration and exploitation in organizational learning. Organization Science, 2(1): 71-87.

March, J. G., Sproull, L. S., \& Tamuz, M. 1991. Learning from samples of one or fewer. Organization Science, 2(1): 1-13.

Mathews, J., \& Zander, I. 2007. The international entrepreneurial dynamics of accelerated internationalisation. Journal of International Business Studies, 38(3): 387-403.

McDermott, G. A., \& Corredoira, R. A. 2010. Network composition, collaborative ties, and upgrading in emerging-market firms: Lessons from the Argentine autoparts sector. Journal of International Business Studies, 41(2): 308-329.

Meyer, K. E., Li, D., \& Schotter, A. 2020. Managing the MNE subsidiary: Advancing a multi-level and dynamic research agenda. Journal of International Business Studies, 51(4): 538-576.

Meyer, K. E., Mudambi, R., \& Narula, R. 2011. Multinational enterprises and local contexts: The opportunities and challenges of multiple embeddedness. Journal of Management Studies, 48(2): 235-252. 
Miller, D., \& Chen, M.-J. 1994. Sources and consequences of competitive inertia: A study of the U.S. airline industry. Administrative Science Quarterly, 39(1): 1-23.

Myers, C. G. 2018. Coactive vicarious learning: Toward a relational theory of vicarious learning in organizations. Academy of Management Review, 43(4): 610-634.

Nachum, L., \& Song, S. 2011. The MNE as a portfolio: Interdependencies in MNE growth trajectory. Journal of International Business Studies, 42(3): 381-405.

Narula, R. 2006. Globalization, new ecologies, new zoologies, and the purported death of the eclectic paradigm. Asia Pacific Journal of Management, 23(2): 143-151.

Narula, R. 2012. Do we need different frameworks to explain infant MNEs from developing countries? Global Strategy Journal, 2(3): 188-204.

Narula, R. 2014. Exploring the paradox of competence-creating subsidiaries: Balancing bandwidth and dispersion in MNEs. Long Range Planning, 47(1/2): 4-15.

Narula, R., Asmussen, C. G., Chi, T., \& Kundu, S. K. 2019. Applying and advancing internalization theory: The multinational enterprise in the twenty-first century. Journal of International Business Studies, 50(8): 1231-1252.

Narula, R., \& Verbeke, A. 2015. Making internalization theory good for practice: The essence of Alan Rugman's contributions to international business. Journal of World Business, 50(4): 612-622.

Nelson, R. R., \& Winter, S. G. 1982. An evolutionary theory of economic change. Boston, MA: Belknap.

Papadakis, V. M., Lioukas, S., \& Chambers, D. 1998. Strategic decision-making processes: The role of management and context. Strategic Management Journal, 19(2): 115-147.

Pedersen, T., \& Shaver, J. M. 2011. Internationalization revisited: The big step hypothesis. Global Strategy Journal, 1(3-4): 263-274.

Pentland, B. T., \& Rueter, H. H. 1994. Organizational routines as grammars of action. Administrative Science Quarterly, 39(3): 484-510.

Perkins, S. E. 2014. When does prior experience pay? Institutional experience and the multinational corporation. Administrative Science Quarterly, 59(1): 145-181.

Petersen, B., Pedersen, T., \& Sharma, D. D. 2003. The role of knowledge in firms' internationalization process: Wherefrom and whereto? In A. Blomstermo \& D. D. Sharma (Eds.): Learning in the internationalisation process of firms. Cheltenham: Edward Elgar.

Posen, H. E., Keil, T., Kim, S., \& Meissner, F. D. 2018. Renewing research on problemistic search-A review and research agenda. Academy of Management Annals, 12(1): 208-251.

Puig, F., Madhok, A., \& Shen, Z. 2020. Investigating firm heterogeneity in country-of-origin cluster location choice decisions. Multinational Business Review, 28(2): 221-244.

Putzhammer, M., Fainshmidt, S., Puck, J., \& Slangen, A. 2018. To elevate or to duplicate? Experiential learning, host-country institutions, and MNE post-entry commitment increase. Journal of World Business, 53(4): 568-580.

Rugman, A. M. 1980. A new theory of the multinational enterprise-Internationalization versus internalization. Columbia Journal of World Business, 15(1): 23-29.

Rugman, A. M., \& Verbeke, A. 2004. A perspective on regional and global strategies of multinational enterprises. Journal of International Business Studies, 35(1): 3-18.

Rugman, A. M., Verbeke, A., \& Nguyen, Q. T. K. 2011. Fifty years of international business theory and beyond. Management International Review, 51(6): 755-786.

Santangelo, G. D., \& Meyer, K. E. 2011. Extending the internationalization process model: Increases and decreases of MNE commitment in emerging economies. Journal of International Business Studies, 42(7): 894-909.

Santangelo, G. D., \& Meyer, K. E. 2017. Internationalization as an evolutionary process. Journal of International Business Studies, 48(9): 1114-1130.
Sapienza, H., Autio, E., George, G., \& Zahra, S. 2006. A capabilities perspective on the effects of early internationalization on firm survival and growth. Academy of Management Review, 31(4): 914-933.

Shinkle, G. A. 2012. Organizational aspirations, reference points, and goals. Journal of Management, 38(1): 415-455.

Su, Y., \& Si, S. 2015. What motivates financial innovation across countries? The influences of performance aspiration and economic freedom. Management International Review, 55(4): 563-587.

Surdu, I., Mellahi, K., \& Glaister, K. W. 2019. Once bitten, not necessarily shy? Determinants of foreign market re-entry commitment strategies. Journal of International Business Studies, 50(3): 393-422.

Surdu, I., Mellahi, K., Glaister, K. W., \& Nardella, G. 2018. Why wait? Organizational learning, institutional quality and the speed of foreign market re-entry after initial entry and exit. Journal of World Business, 53(6): 911-929.

Surdu, I., \& Narula, R. 2020. Organizational learning, unlearning and re-internationalization timing: Differences between emerging- versus developed-market MNEs. Journal of International Management. https://doi.org/10.1016/j.intman.2020. 100784.

Sutherland, D., Anderson, J., \& Hu, Z. 2020. A comparative analysis of location and non-location-bounded strategic asset seeking in emerging and developed market MNEs: An application of new internalization theory. International Business Review, 29(2): 101635.

Teece, D. J. 1986. Transaction cost economics and the multinational enterprise: An assessment. Journal of Economic Behavior \& Organization, 7(1): 21-45.

Thams, Y., Alvarado-Vargas, M. J., \& Newburry, W. 2016. Geographical diversification as a predictor of MNC reputations in their home nations. Journal of Business Research, 69(8): 2882-2889.

Trichterborn, A., Zu Knyphausen-Aufseß, D., \& Schweizer, L. 2016. How to improve acquisition performance: The role of a dedicated M\&A function, M\&A learning process, and M\&A capability. Strategic Management Journal, 37(4): 763-773.

Vahlne, J.-E. 2020. Development of the Uppsala model of internationalization process: From internationalization to evolution. Global Strategy Journal, 10(2): 239-250.

Verbeke, A. 2009. International business strategy: Rethinking the foundations of global corporate success. Cambridge: Cambridge University Press.

Verbeke, A., \& Greidanus, N. 2009. The end of the opportunism vs trust debate: Bounded reliability as a new envelope concept in research on MNE governance. Journal of International Business Studies, 40(9): 1471-1495.

Vermeulen, F., \& Barkema, H. G. 2001. Learning through acquisitions. Academy of Management Journal, 44(3): 457-476.

Welch, C. L., \& Welch, L. S. 2009. Re-internationalisation: Exploration and conceptualisation. International Business Review, 18(6): 567-577.

Yip, G. S. 1989. Global strategy... in a world of nations? Sloan Management Review, 31(1): 29-41.

Zeng, Y., Shenkar, O., Lee, S.-H., \& Song, S. 2013. Cultural differences, MNE learning abilities, and the effect of experience on subsidiary mortality in a dissimilar culture: Evidence from Korean MNEs. Journal of International Business Studies, 44(1): 42-65.

Zhang, C. M., \& Greve, H. R. 2019. Dominant coalitions directing acquisitions: Different decision makers, different decisions. Academy of Management Journal, 62(1): 44-65.

Zollo, M., \& Reuer, J. J. 2010. Experience spillovers across corporate development activities. Organization Science, 21(6): 1195-1212. 


\section{ABOUT THE AUTHORS}

Irina Surdu is an Associate Professor of International Business Strategy at Warwick Business School, University of Warwick, UK. Her current research agenda focuses on the international growth and subsequent investment strategies of MNEs, with a particular interest in their exit and reentry strategies. Recent works appear in Journal of International Business Studies, British Journal of Management and Journal of International Management, among others.

Henrich R. Greve is the Rudolf and Valeria Maag Chaired Professor of Entrepreneurship at INSEAD. He received his Ph.D. from Stanford University's Graduate School of Business. His current research is organizational learning from performance feedback and aspiration levels, organizational adaptation to institutional environments, and (football) team performance and misconduct.

Gabriel R. G. Benito is Professor at the Department of Strategy and Entrepreneurship, BI Norwegian Business School, Oslo. He is a Fellow of Academy of International Business and a Fellow of European
International Business Academy. His current research agenda focuses on corporate governance, the strategies and organization of multinational enterprises, and the economic organization of international business.

Open Access This article is licensed under a Creative Commons Attribution 4.0 International License, which permits use, sharing, adaptation, distribution and reproduction in any medium or format, as long as you give appropriate credit to the original author(s) and the source, provide a link to the Creative Commons licence, and indicate if changes were made. The images or other third party material in this article are included in the article's Creative Commons licence, unless indicated otherwise in a credit line to the material. If material is not included in the article's Creative Commons licence and your intended use is not permitted by statutory regulation or exceeds the permitted use, you will need to obtain permission directly from the copyright holder. To view a copy of this licence, visit http://creativecommons.org/licenses/by/4.0/.

Publisher's Note Springer Nature remains neutral with regard to jurisdictional claims in published maps and institutional affiliations.

Accepted by Rajneesh Narula, Area Editor, 22 October 2020. This article has been with the authors for two revisions. 